\title{
FUNGSI MOTIF PENGHAKIMAN ALLAH DI 2 TESALONIKA 2:1-12 MENURUT PENDEKATAN ANALISIS WACANA*
}

\author{
Alexander Darmawan Limasaputra**
}

\begin{abstract}
This article discusses about the function of the motive of God's judgment found in 2 Thessalonians 2:1-12. The research analysis in this article uses a discourse analysis approach. Discourse analysis is a broad umbrella for all methods to analyze languages not from the level of words or sentences, but at a higher level, namely to analyze the relationships between sentences, paragraphs, broader units and the text as a whole. The aspects of discourse analysis used in this article are discourse markers and information structure analysis. Discourse analysis approach is useful especially because the Epistle of 2 Thessalonians is used by Paul as a mean of communication to the Thessalonians. The analysis results of this article will explain that the function of God's judgment in 2 Thessalonians 2:1-12 is to comfort and strengthen the Thessalonians so that their faith is not shaken and they do not fear the claims that the day of the Lord has come.
\end{abstract}

Keywords: discourse analysis, discourse markers, information structure analysis, God's judgment, 2 Thessalonians.

Abstrak: Artikel ini membahas fungsi motif penghakiman Allah yang terdapat di 2 Tesalonika 2:1-12. Analisis penelitian di dalam artikel ini menggunakan pendekatan analisis wacana (AW). AW merupakan payung besar untuk semua metode yang menganalisis bahasa bukan dari tingkat kata atau kalimat, tetapi menganalisis bahasa dengan tingkat yang lebih tinggi daripada kata dan kalimat, yaitu menganalisis

* Artikel ini merupakan bagian dari tesis pada program studi Magister Teologi yang telah diuji di Sekolah Tinggi Teologi Amanat Agung.

** Penulis adalah rohaniwan Gereja Beritakan Injil Bogor. Penulis dapat dihubungi melalui email: alexander.darmawan@gmail.com. 
hubungan antar kalimat, paragraf, unit yang lebih luas dan teks secara keseluruhan. Aspek AW yang digunakan dalam artikel ini adalah analisis markah wacana dan analisis struktur informasi. Pendekatan AW bermanfaat terkhusus 2 Tesalonika merupakan sebuah surat yang menjadi alat komunikasi Paulus kepada jemaat Tesalonika. Hasil analisis dalam artikel ini akan memperlihatkan bahwa fungsi motif penghakiman Allah di 2 Tesalonika 2:1-12 adalah menghibur dan menguatkan jemaat Tesalonika supaya mereka tidak guncang dan takut dari klaim palsu yang menyatakan hari Tuhan telah tiba.

Kata-kata kunci: analisis wacana, markah wacana, analisis struktur informasi, penghakiman Allah, 2 Tesalonika.

\section{Pendahuluan}

Tema penghakiman Allah bukanlah tema yang populer. Orang lebih suka membicarakan tema kasih, anugerah, berkat dan pengampunan Allah. ${ }^{1}$ Namun demikian, tema penghakiman Allah tidak dapat diabaikan karena terdapat di seluruh Perjanjian Lama dan Perjanjian Baru. ${ }^{2}$ Penghakiman Allah merupakan bagian dari keberadaan Allah sendiri sebagai Hakim atas manusia di mana suatu saat nanti setiap manusia harus mempertanggungjawabkan segala hal yang dilakukannya di hadapan takhta penghakiman Allah. ${ }^{3}$

Melakukan penelitian mengenai penghakiman Allah di 2 Tesalonika 2:1-12 merupakan hal penting karena, pertama, terdapat

1. Matthew D. Aernie dan Donald E. Hartley, The Righteous and Merciful Judge (Bellingham: Lexham, 2018), 1-2.

2. Tema penghakiman di seluruh Perjanjian Lama dan Perjanjian Baru dapat dilihat di James M. Hamilton Jr., God's Glory in Salvation Through Judgment: A Biblical Theology (Wheaton: Crossway, 2010).

3. Leon Morris, Teologi Perjanjian Baru, terj. H. Pidyarto O Carm (Malang: Gandum Mas, 2006), 32-33. 
banyak istilah yang terkait dengan penghakiman Allah, yaitu, Tapovoía di

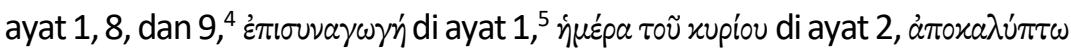
di ayat 3, 6, 8, dan $x p i v \omega$ di ayat $12 .{ }^{6}$ Kedua, penghakiman Allah merupakan bagian dari pengajaran eskatologis yang merupakan tema dominan di dalam 2 Tesalonika. ${ }^{7}$

Banyaknya istilah yang terkait dengan penghakiman Allah menimbulkan pertanyaan mengenai fungsi motif penghakiman Allah di 2 Tesalonika 2:1-12. Untuk itu tujuan artikel ini adalah untuk memahami fungsi motif penghakiman Allah di 2 Tesalonika 2:1-12 melalui pendekatan analisis wacana (AW). ${ }^{8}$

\section{Metode Analisis Wacana}

Stephen $\mathrm{H}$. Levinsohn mendefinisikan AW sebagai berikut,

Discourse analysis is an analysis of language features that draws its explanations, not from within the sentence or word (i.e., the factors

4. Jeffrey A. D. Weima, 1-2 Thessalonians, BECNT (Grand Rapids: Baker Academic, 2014), 205; Charles A. Wanamaker, The Epistles to the Thessalonians, NIGTC (Grand Rapids: Eerdmans, 1990), 125, 237.

5. Weima, 1-2 Thessalonians, 500; I. Howard Marshall, 1 and 2 Thessalonians, NCB (Grand Rapids: Eerdmans, 1983), 185-86.

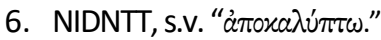

7. Abraham J. Malherbe, The Letters to the Thessalonians, AYB (New Haven: Yale, 2008), 351.

8. Analisis wacana disebut juga dengan discourse analysis. Pembahasan lebih lanjut mengenai analisis wacana dan tema penghakiman Allah yang adil di 2 Tesalonika 1:3-10 dapat dilihat di Alexander Darmawan Limasaputra, "Bukti Penghakiman Allah Yang Adil di dalam 2 Tesalonika 1:3-10 Menurut Pendekatan Analisis Wacana," Veritas: Jurnal Teologi dan Pelayanan 19, no. 1 (Juni 2020): 69-84.. DOI: https://doi.org/10.36421/veritas.v19i1.349. 
involved are not syntactic or morphological), but extrasententially (from the linguistic and wider context). ${ }^{9}$

Artikel ini melakukan analisis dengan pendekatan AW dari kelompok Amerika Utara. ${ }^{10}$ Pendekatan AW dari kelompok Amerika Utara dikembangkan oleh Summer Institute of Linguistics (SIL). Para sarjana yang berada di SIL antara lain adalah Stephen H. Levinsohn, E. A. Nida dan S. M. Lamb. ${ }^{11}$ Steven E. Runge meski bukan bagian langsung dari SIL, tetapi ia belajar dan bergantung kepada Levinsohn serta menilai Levinsohn sebagai mentornya. ${ }^{12}$ Pendekatan AW dari kelompok Amerika Utara akan dipaparkan lebih lanjut melalui analisis discourse markers (markah wacana $)^{13}$ dengan pendekatan fungsional dan analisis struktur informasi. Dua analisis ini membantu pembaca dalam memproses alur argumentasi dan membantu pembaca mengetahui maksud yang ingin lebih ditekankan atau ditandai oleh penulis ketika ia mengomunikasikan pesannya. ${ }^{14}$

9. Stephen H. Levinsohn, Discourse Features of New Testament Greek, ed. ke-2 (Dallas: SIL International, 2000), viii.

10. Stanley E. Porter menjelaskan bahwa terdapat empat kelompok pendekatan DA, yaitu: Inggris dan Australia, Eropa Kontinental, Afrika Selatan, dan Amerika Utara. Untuk memperhatikan kelebihan dan kelemahan dari setiap kelompok dapat dilihat di Stanley E. Porter, "Discourse Analysis and New Testament Studies: An Introductory Survey," dalam Discourse Analysis and Other Topics in Biblical Greek, ed. Stanley E. Porter dan D. A. Carson, JSNTS 113 (Sheffield: Sheffield Academic, 1995), 24-35.

11. Porter, "Discourse Analysis," 24; Constantine R. Campbell, Advances in the Study of Greek (Grand Rapids: Zondervan, 2015), 150.

12. Steven E. Runge, "Introduction: Why We're Honoring Stephen H. Levinsohn," dalam Discourse Studies and Biblical Interpretation: A Festschrift in Honor of Stephen H. Levinsohn, ed. Steven E. Runge (Bellingham: Logos Bible Software, 2011), 3.

13. Selanjutnya discourse markers akan disebut dengan markah wacana.

14. Christopher James Fresch, "Discourse Markers in the Septuagint and Early Koine Greek with Special Reference to The Twelve" (Disertasi Ph.D, University of 


\section{Analisis Markah Wacana dengan Pendekatan Fungsional}

Analisis markah wacana merupakan perangkat pragmatika yang memberi sinyal kepada pembaca bagaimana memproses dan memahami kalimat atau paragraf. ${ }^{15}$ Markah wacana dapat dianggap sebagai rambu jalan linguistik yang membantu pembaca dalam menavigasi kalimat atau paragraf, memberi tahu mengenai struktur teks, memberi tahu apa yang ada di depan teks, dan memberi instruksi bagaimana cara memproses suatu teks. $^{16}$

Teori pendekatan fungsional menjelaskan bahwa setiap markah wacana memiliki satu fungsi pragmatika inti yang dapat diamati dalam setiap pemunculannya. ${ }^{17}$ Perlu diperhatikan bahwa di dalam satu fungsi pragmatika inti dapat diberikan makna semantik yang berbeda-beda tergantung proses pragmatika, konteks dan prosodi di mana markah wacana itu muncul. Pendekatan yang memandang markah wacana memiliki satu fungsi pragmatika inti dikenal sebagai monosemi. ${ }^{18}$

Di bawah ini akan dipaparkan fungsi pragmatika inti markah wacana dengan pendekatan fungsional monosemi. Yang pertama adalah xaí. Terdapat dua jenis xaí. Jenis xaí yang pertama adalah konjungtif xaí

Cambridge, 2015), 4; Steven E. Runge, "Interpreting Constituent Order in Koine Greek," dalam Linguistics and New Testament Greek, ed. David Alan Black dan Benjamin L. Merkle (Grand Rapids: Baker Academic, 2020), 127.

15. Fresch, "Discourse Markers," 4.

16. Fresch, "Discourse Markers," 4.

17. Fungsi pragmatika berkaitan dengan penataan wacana menjadi bagianbagian yang lebih kecil yang memudahkan proses kognitif (Jonly Joihin, "A Functional Description of the Discourse Marker $\Delta \mathrm{E}$ in 1 Corinthians" (Disertasi Ph.D, The Southern Baptist Theological Seminary, 2019), 6).

18. Fresch, "Discourse Markers," 5. 
yang berfungsi memberi tanda aditif atau asosiatif, ${ }_{19}^{19}$ maksudnya berfungsi menambah atau menghubungkan antara kalimat atau paragraf terlepas apakah ada atau tidak adanya kontinuitas semantik di antara elemenelemen tersebut. ${ }^{20}$ Jenis $x$ aí yang kedua adalah nonkonjungtif $x a i$ atau yang disebut juga dengan adverbial $\varkappa a i^{2}{ }^{21}$ yang berfungsi memberi tanda aditif. ${ }^{22}$ Di dalam nonkonjungtif xaí, fungsi aditif tidak berfungsi menghubungkan kalimat atau paragraf, tetapi berfungsi memberi tambahan konfirmasi atau paralelisme atas kalimat atau paragraf yang telah ada sebelumnya. ${ }^{23}$ Yang kedua adalah $\delta \varepsilon ́$. Markah wacana $\delta \varepsilon ́$ berfungsi memberi tanda sebuah unit informasi baru, ${ }^{24}$ maksudnya $\delta \varepsilon ́$ berfungsi untuk menandai adanya segmen yang baru dan berbeda di dalam suatu cerita, topik atau argumen. ${ }^{25}$

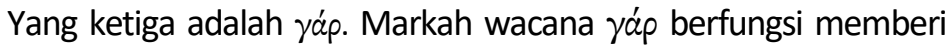
tanda penguatan, ${ }^{26}$ maksudnya $\gamma \alpha \dot{\rho}$ berfungsi menandai suatu kalimat atau paragraf yang merupakan penjelasan lebih lanjut dari proposisi (argumen) sebelumnya dengan cara memperkuat atau mendukung kalimat atau proposisi tersebut. ${ }^{27}$ Selain memberi tanda penguatan, markah wacana $\gamma a ́ p$

19. Levinsohn, Discourse Features, 124.

20. Runge, Discourse Grammar, 23-26; Levinsohn, Discourse Features, 124-26.

21. Levinsohn, Discourse Features, 99.

22. Levinsohn, Discourse Features, 99.

23. Levinsohn, Discourse Features, 99.

24. Joihin, "A Functional Description of the Discourse Marker," 6; Stephen H. Levinsohn, "Eight Constraints on the Interpretation of Luke 17:11-19" (makalah dipresentasikan pada pertemuan Society of Biblical Literature di Vienna, Austria, Juli 2014), 6.

25. Fresch, "Discourse Markers," 72.

26. Levinsohn, Discourse Features, 91; Stephen H. Levinsohn, "A Holistic Approach to the Argument Structure of Romans 6" (makalah dipresentasikan pada pertemuan Society of Biblical Literature di London, Inggris, Juli 2001), 3.

27. Runge, Discourse Grammar, 51-54; Levinsohn, Discourse Features, 92. 
juga dapat memberi tanda memperkenalkan poin baru, ${ }^{28}$ maksudnya $\gamma \alpha \dot{\rho}$ berfungsi memberi dasar alasan bagi pembahasan yang akan dijelaskan lebih lanjut di kalimat atau paragraf selanjutnya. ${ }^{29}$ Yang keempat adalah $\dot{\alpha} \lambda \lambda \dot{\alpha}$. Markah wacana à $\lambda \lambda \alpha ́$ berfungsi memberi tanda korektif,, ${ }^{30}$ maksudnya

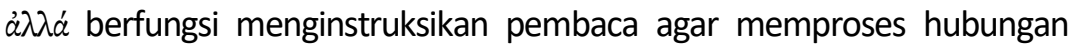
korektif di antara dua bagian informasi yang ada di dalam kalimat atau paragraf. ${ }^{31}$

Yang kelima adalah $\omega َ \tau \varepsilon$. Markah wacana $\omega ّ \sigma \varepsilon$ berfungsi memberi tanda inferensial dan hasil, ${ }^{32}$ maksudnya ketika $\omega \check{\sigma \tau \varepsilon}$ berada di dalam suatu kalimat atau paragraf, $̋ َ \tau \varepsilon$ membatasi apa yang ditafsirkan sebagai "hasil" dari apa yang dinyatakan sebelumnya. ${ }^{33}$ Yang keenam adalah ỡv. Markah wacana oũv berfungsi memberi tanda inferensial dan distingtif,, ${ }^{34}$ maksudnya oũv berfungsi menandai adanya hubungan dan perkembangan yang baru yang ada di dalam suatu kalimat atau paragraf. Tetapi perkembangan baru ini ditandai dengan menambahkan penjelasan yang

28. Stephen H. Levinsohn, "Some Constraints on Discourse Development in the Pastoral Epistles," dalam Discourse Analysis and the New Testament: Approaches and Results, ed. Stanley E. Porter dan Jeffrey T. Reed, JSNTS (Sheffield: Sheffield Academic, 1999), 319.

29. Levinsohn, "Some Constraints on Discourse Development in the Pastoral Epistles," 319-20.

30. Fresch, "Discourse Markers," 151; Runge, Discourse Grammar, 93.

31. Fresch, "Discourse Markers," 151, 169.

32. Stephen H. Levinsohn, "'"Therefore" or "Wherefore": What's the Difference?," dalam Explorations in Ancient Syriac, Hebrew, and Greek Sources, ed. Richard A. Taylor dan Craig E. Morrison (Piscataway: Gorgias Press, 2014), 334.

33. Levinsohn, "'"Therefore" or "Wherefore,"'" 334.

34. Levinsohn, "'"Therefore" or "Wherefore,"'" 327. 
memiliki kesinambungan erat dengan kalimat, paragraf atau bagian sebelumnya. ${ }^{35}$

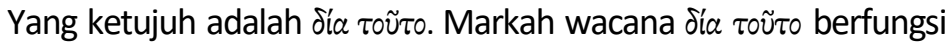

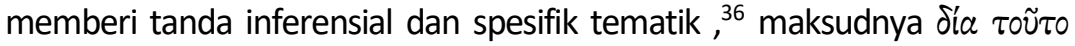
berfungsi menandai adanya hubungan di antara dua kalimat, paragraf dan menunjukkan perkembangan baru yang berbeda di dalam kalimat, paragraf atau bagian, serta menjelaskan adanya sebab akibat dengan kalimat,

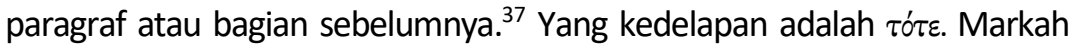
wacana $\tau o ́ \tau \varepsilon$ berfungsi memberi tanda perkembangan yang berbeda dan temporal, ${ }^{38}$ maksudnya $\tau o ́ \tau \varepsilon$ berfungsi menandai bahwa kalimat atau paragraf yang ada sebelumnya dan kalimat atau paragraf yang ada selanjutnya merupakan perkembangan yang berbeda dan bersifat temporal. ${ }^{39}$ Yang kesembilan adalah "̈ $\tau$. Markah wacana ö $\tau$ เ berfungsi memberi tanda kausal, ${ }^{40}$ maksudnya ö $\tau$ ı berfungsi menandai adanya hubungan kausal antara kalimat atau paragraf. ${ }^{41}$ Selain berfungsi memberi tanda kausal, markah wacana ö $\tau$ dapat berfungsi memberi tanda penjelasan yang memperkenalkan dan menjelaskan lebih lanjut kalimat

35. Runge, Discourse Grammar, 43; Levinsohn, Discourse Features, 129.

36. Levinsohn, "''Therefore" or "Wherefore,"'" 336.

37. Runge, Discourse Grammar, 49-50.

38. Runge, Discourse Grammar, 41; Levinsohn, Discourse Features, 98.

39. Runge, Discourse Grammar, 37-38.

40. Jacob N. Cerone, Rick Brannan, dan Kristopher A. Lyle, 1-2 Thessalonians, ed. Steven E. Runge, Lexham Discourse Commentary (Bellingham: Lexham Press, 2018), 1 Tes. 1:5.

41. Cerone, Brannan, dan Lyle, 1-2 Thessalonians, 1 Tes. 1:5. 
atau paragraf yang sudah ada. ${ }^{42}$ Setelah di atas dijelaskan analisis markah wacana dengan pendekatan fungsional, di bawah ini akan dijelaskan analisis struktur informasi.

\section{Analisis Struktur Informasi}

Menurut pendekatan tradisional, struktur informasi di bahasa Yunani dapat dikatakan standar jika urutan kata di dalam kalimat adalah kata kerja, subjek, dan objek. ${ }^{43}$ Ini merupakan pendekatan yang digunakan oleh beberapa ahli tata bahasa seperti A. T. Robertson, Friedrich Blass, Albert Debrunner dan Robert Walter Funk. ${ }^{44}$

Dalam hubungannya dengan perubahan standar urutan kata, ahli tata bahasa tradisional mengemukakan dua alasan terjadinya perubahan standar urutan kata, yaitu untuk memberi tanda kontras dan penekanan. ${ }^{45}$ Runge tidak sepenuhnya mengkritisi pendekatan tradisional. Runge mengkritisi pendekatan tradisional dalam memberi pemahaman mengenai analisis perubahan standar urutan kata karena pemahaman tersebut cenderung bersifat intuitif dan didasarkan kepada kepekaan pragmatik. ${ }^{46}$ Runge berkata,

42. Daniel B. Wallace, Greek Grammar Beyond the Basics (Grand Rapids: Zondervan, 1996), 677-78.

43. Dalam bahasa Indonesia dan Inggris struktur informasi yang sesuai dengan natural information flow adalah subjek, predikat, dan objek (keterangan).

44. A. T. Robertson, A Grammar of the Greek New Testament in the Light of Historical Research (Bellingham: Logos Research Systems, 2006), 417; BDF, §472.

45. Robertson, A Grammar of the Greek, 417-18.

46. Runge, "Interpreting Constituent Order," 127. 
Generally speaking, the traditional approach correctly recognized that fronting information achieved certain effects, and correctly classified them into two basic functions: emphasis and contrast. But they lacked a descriptive framework to explain how or why this happened in a given context. ${ }^{47}$

Berdasarkan penjelasan dan kritik terhadap pendekatan tradisional, Runge memperkenalkan ide mengenai markedness (penandaan) sebagai strategi untuk mengorganisasikan klausa atau kalimat ke dalam kerangka kerja yang koheren dan terpadu. ${ }^{48}$ Ide penandaan mengandaikan bahwa dalam semua posisi yang ada akan terdapat satu posisi yang paling mendasar yang disebut dengan posisi standar. Posisi standar terjadi ketika seorang penulis menempatkan kata kerja di awal kalimat yang kemudian diikuti oleh subjek dan objek. ${ }^{49}$ Posisi standar merupakan pilihan yang digunakan seorang penulis ketika ia memilih untuk tidak memberi sinyal akan hadirnya beberapa fitur pragmatik tertentu. ${ }^{50}$ Berdasarkan posisi standar maka semua posisi lain merupakan posisi tertanda. ${ }^{51}$ Posisi tertanda terjadi ketika seorang penulis menempatkan elemen lain selain kata kerja contohnya subjek dan objek di awal kalimat. ${ }^{52}$ Posisi tertanda adalah posisi yang digunakan seorang penulis ketika ia

47. Steven E. Runge, "Questions From Your Book: Discourse Grammar," diwawancara oleh Alexander Darmawan Limasaputra, e-mail, 10 Juni 2020.

48. Runge, Discourse Grammar, 185.

49. Runge, "Interpreting Constituent Order," 132.

50. Runge, Discourse Grammar, 185; Runge, "Interpreting Constituent Order," 134.

51. Runge, Discourse Grammar, 185; Runge, "Interpreting Constituent Order," 132.

52. Runge, "Interpreting Constituent Order," 132, 136. 
memilih untuk memberi sinyal akan hadirnya fitur tertentu. ${ }^{53}$ Runge menjabarkan ide penandaan ke dalam dua posisi yaitu frame of reference (kerangka acuan) dan emphasis (penekanan)..$^{54}$

Kerangka acuan merupakan posisi yang menjelaskan pilihan seorang penulis untuk menempatkan informasi yang sudah diketahui ke dalam posisi tertanda. ${ }^{55}$ Runge menjelaskan bahwa kerangka acuan memiliki tiga kegunaan, ${ }^{56}$ pertama, menyediakan kerangka bagi klausa yang mengikutinya; kedua, menyediakan titik awal dalam penyusunan suatu wacana; ketiga, menyediakan dasar untuk menghubungkan apa yang ada di depan dan apa yang ada di belakang kerangka. Menurut tiga kegunaan ini, kerangka acuan bukanlah informasi yang terpenting di dalam klausa. ${ }^{57}$

Ada kalanya seorang penulis memilih tindakan dengan menarik perhatian ekstra pembaca kepada informasi yang baru dan yang paling penting. Tindakan pemilihan penulis ini disebut dengan penekanan. ${ }^{58}$ Penekanan merupakan posisi yang menjelaskan pilihan seorang penulis untuk menempatkan informasi baru atau informasi yang paling penting

53. Runge, Discourse Grammar, 185, 190.

54. Pemahaman Runge mengenai kerangka acuan dan penekanan mengikuti Simon C. Dik (Runge, Discourse Grammar, 189-90); bdk. Simon C. Dik, The Theory of Functional Grammar: Part I: The Structure of the Clause, ed. Kees Hengeveld, ed. ke-2 (Berlin: Moulton de Gruyter, 1997).

55. Runge, Discourse Grammar, 194, 207. Levinsohn mengistilahkan kerangka acuan dengan istilah point of departure (Levinsohn, Discourse Features, 8).

56. Steven E. Runge, The Lexham Discourse Greek New Testament: Glossary (Bellingham: Lexham Press, 2008), Frame of Reference.

57. Runge, The Lexham Discourse Greek: Glossary, Frame of Reference.

58. Runge, Discourse Grammar, 272. 
kepada posisi tertanda. ${ }^{59}$ Setelah di atas dijelaskan analisis struktur informasi, di bawah ini akan ada pembahasan 2 Tesalonika 2:1-12.

\section{Pembahasan 2 Tesalonika 2:1-12}

Untuk memperjelas penelitian, berikut ini digambarkan bagan argumentasi 2 Tesalonika 2:1-12 berdasarkan penggunaan markah wacana.

Bagan Argumentasi 2 Tesalonika 2:1-12.

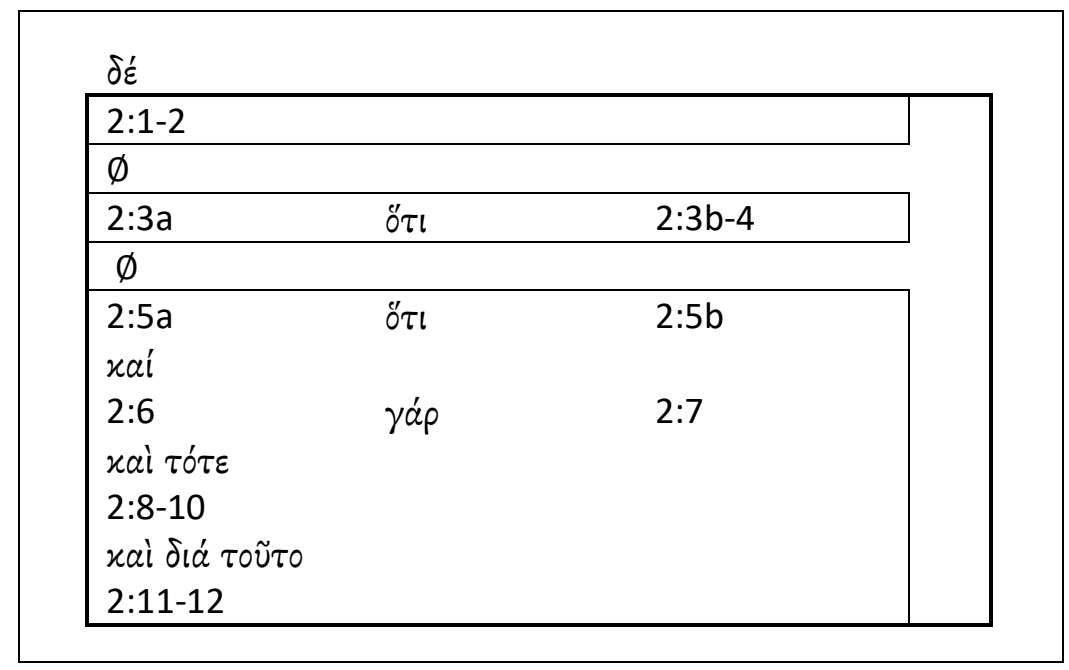

Sebagai pengantar pembahasan bagan argumentasi, dapat diperhatikan bahwa 2 Tesalonika 2:1-12 merupakan satu perikop yang terdiri tiga bagian argumentasi, yaitu ayat $1-2$, ayat 3-4, dan ayat 5-12. Di antara ayat 2 dan 3 , ayat 4 dan 5 terdapat asidenton $(\varnothing)$. Asidenton merujuk kepada penghubungan kalimat atau paragraf tanpa menggunakan markah

59. Runge, Discourse Grammar, 190. 
wacana. ${ }^{60}$ Di bagian pertama (ay. 1-2), terdapat markah wacana $\delta \varepsilon ́$ di ayat 1 yang berfungsi memberi tanda unit informasi baru. ${ }^{61}$ Di bagian kedua (ay. 3-4), terdapat markah wacana ö ı di ayat 3 yang berfungsi memberi tanda adanya hubungan kasual antara ayat 3b-4 dengan $3 a{ }^{62}$ Di bagian ketiga (ay.

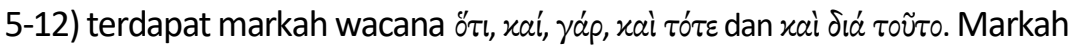
wacana $0 \ddot{\tau} \iota$ di ayat 5 berfungsi memberi tanda adanya hubungan kausal antara ayat $5 \mathrm{~b}$ dengan 5 a. ${ }^{63}$ Markah wacana xaí di ayat 6 berfungsi memberi tanda aditif atau asosiatif yang menghubungkan kalimat atau paragraf yang ada di ayat 5a sampai ayat $6 .{ }^{64}$ Markah wacana yáp di ayat 7 berfungsi sebagai tanda penguatan, atau berfungsi memberi tanda adanya penjelasan lebih lanjut atau latar belakang dari kalimat atau paragraf yang terdapat di ayat $3 b-6 .{ }^{65}$ Markah wacana xaí di ayat 8 berfungsi memberi tanda adanya kelanjutan penjelasan mengenai manusia durhaka yang ada di ayat 3-7.6 ${ }^{66} \mathrm{Di}$ ayat 8 a juga terdapat markah wacana $\tau o ́ \tau \varepsilon$ berfungsi memberi tanda adanya keterkaitan dan perkembangan baru yang bersifat temporal di dalam suatu kalimat antara ayat 10 dan ayat $11 .{ }^{67}$ Di ayat 11 terdapat markah wacana xaí yang memberi tanda adanya hubungan antara perkataan Paulus di ayat 11 dengan ayat $10 .{ }^{68}$ Adanya hubungan ini ditandai

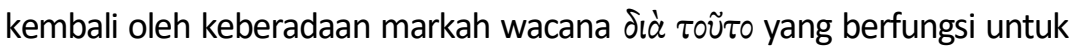

60. Runge, Discourse Grammar, 20-23.

61. Cerone, Brannan, dan Lyle, 1-2 Thessalonians, 2Tes. 2:1.

62. Cerone, Brannan, dan Lyle, 1-2 Thessalonians, 2Tes. 2:3.

63. Cerone, Brannan, dan Lyle, 1-2 Thessalonians, 2Tes. 2:5.

64. Cerone, Brannan, dan Lyle, 1-2 Thessalonians, 2Tes. 2:6.

65. Cerone, Brannan, dan Lyle, 1-2 Thessalonians, 2Tes. 2:7.

66. Cerone, Brannan, dan Lyle, 1-2 Thessalonians, 2Tes. 2:8.

67. Cerone, Brannan, dan Lyle, 1-2 Thessalonians, 2Tes. 2:8.

68. Cerone, Brannan, dan Lyle, 1-2 Thessalonians, 2Tes. 2:11. 


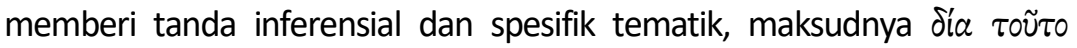
berfungsi menandai adanya sebab akibat antara ayat 10 dengan ayat $11 .{ }^{69}$

Setelah dipaparkan bagan argumentasi, di bawah ini akan diuraikan eksegesis 2 Tesalonika 2:1-12 yang terbagi ke dalam tiga bagian: ${ }^{70}$ (1) ayat 1-2 membahas permasalahan mengenai kedatangan hari Tuhan; (2) ayat 3-4 membahas peristiwa-peristiwa yang akan mendahului kedatangan hari Tuhan; (3) ayat 5-12 membahas mengenai penghakiman Allah yang akan terjadi pada kedatangan hari Tuhan.

\section{Permasalahan Mengenai Kedatangan Hari Tuhan (2 Tesalonika 2:1-2)}

Di 2 Tesalonika 2:1-12, Paulus menjawab permasalahan yang ada di jemaat Tesalonika mengenai kedatangan hari Tuhan. ${ }^{71}$ Permasalahan mengenai kedatangan hari Tuhan dipaparkan Paulus di ayat 1 dan 2.

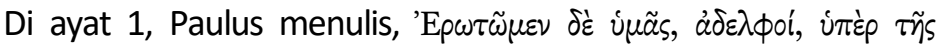

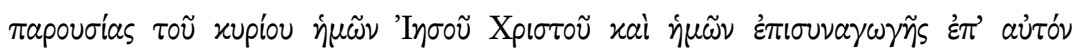
(sekarang kami meminta kalian, saudara-saudara, mengenai kedatangan Tuhan kita Yesus Kristus dan terhimpunnya kita dengan-Nya). ${ }^{72}$ Kata "meminta" ditulis Paulus di awal ayat 1 untuk menjelaskan kepada jemaat Tesalonika mengenai permintaannya. ${ }^{73} \mathrm{Di}$ sini, Paulus tidak langsung menguraikan isi permintaannya. Paulus sebaliknya pertama-tama

69. Cerone, Brannan, dan Lyle, 1-2 Thessalonians, 2Tes. 2:11.

70. Pembagian tiga tahap di dalam 2 Tesalonika 2:1-12 diadaptasi dari Gordon D. Fee, The First and Second Letters to the Thessalonians, NICNT (Grand Rapids: Eerdmans, 2009), 270.

71. Fee, Thessalonians, 269.

72. Terjemahan bahasa Indonesia perikop 2 Tesalonika 2:1-12 di artikel ini merupakan terjemahan penulis sendiri.

73. Marshall, 1 and 2 Thessalonians, 185. 
menetapkan kerangka acuan melalui keberadaan dua frasa preposisi yang dihubungkan oleh markah wacana xaí (dan), yaitu mengenai kedatangan Tuhan kita Yesus Kristus dan terhimpunnya kita dengan-Nya ${ }^{74}$ Informasi di dalam kerangka wacana berfungsi sebagai bingkai yang melaluinya teks 2 Tesalonika 2:1-12 dapat dipahami sebagai sebuah perikop yang isinya saling terkait. ${ }^{75}$ Informasi di dalam kerangka acuan yang perlu diperhatikan adalah kata "kedatangan" dan "terhimpunnya." Paulus memakai kata "kedatangan" untuk merujuk kedatangan Yesus Kristus di masa depan, ${ }^{76}$ sedangkan "terhimpunnya" merujuk kepada pertemuan eskatologis orangorang percaya dengan Yesus Kristus. ${ }^{77}$

Di ayat 2a, Paulus menguraikan isi tujuan permintaannya melalui

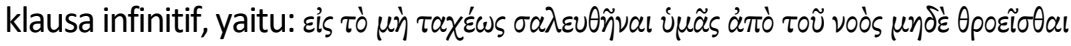
(supaya kalian jangan cepat diguncangkan dari dalam pikiran dan tidak juga ditakutkan). ${ }^{78}$ Tujuan Paulus menggunakan frasa "diguncangkan dari dalam pikiran" adalah supaya pemahaman intelektual jemaat Tesalonika terhadap kedatangan hari Tuhan tetap stabil, tidak guncang atau terombang-ambing meski terdapat pengajaran palsu yang menyatakan hari Tuhan telah tiba. ${ }^{79}$ Di klausa infinitif ini juga terdapat kata "ditakutkan" yang merujuk kepada

74. Cerone, Brannan, dan Lyle, 1-2 Thessalonians, 2Tes. 2:1.

75. Cerone, Brannan, dan Lyle, 1-2 Thessalonians, 2Tes. 2:1.

76. Weima, 1-2 Thessalonians, 204-5.

77. Weima, 1-2 Thessalonians, 500.

78. Wallace menjelaskan bahwa partikel घis yang diikuti oleh infinitif menjelaskan tujuan (Wallace, Greek Grammar, 590-1). Lihat juga William D. Mounce, Basics of Biblical Greek Grammar, ed. ke-4 (Grand Rapids: Zondervan, 2019), 373.

79. Malherbe, Thessalonians, 416; Gene L. Green, The Letters to the Thessalonians, PNTC (Grand Rapids: Eerdmans, 2002), 303. 
keadaan gangguan mental yang dipicu oleh pengajaran palsu yang menyatakan hari Tuhan telah tiba. ${ }^{80}$

Di antara klausa infinitif terdapat kata $\mu \eta \delta \varepsilon ́$ (dan tidak juga) yang berfungsi memberi tanda ascensive (kenaikan), ${ }^{81}$ yaitu menunjukkan dua negasi yang semakin bertambah dan eksklusif. ${ }^{82}$ Di dalam bagian ini negasi kata "diguncangkan" semakin bertambah oleh kata "ditakutkan." Keberadaan istilah "dan tidak juga" menambahkan negasi nasihat Paulus supaya jemaat Tesalonika tidak diguncangkan dan ditakutkan dari sumbersumber yang berkata bahwa hari Tuhan telah tiba.

Di ayat 2a juga terdapat penekanan, yaitu kata keterangan "cepat" karena berada di depan kata infinitif "diguncangkan" dan merupakan informasi yang baru muncul. ${ }^{83}$ Tujuan penekanan adalah menekankan supaya jemaat Tesalonika tidak cepat diguncangkan ketika mendengar pengajaran palsu. ${ }^{84} \mathrm{Di}$ ayat $2 \mathrm{~b}$, Paulus membuat daftar kemungkinan

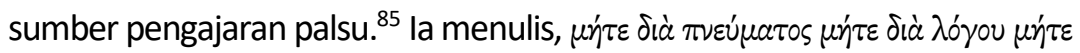

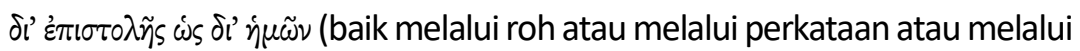
surat seolah-olah dari kami). Perlu diperhatikan bahwa Paulus menghubungkan tiga sumber pengajaran palsu ini dengan $\mu \dot{\gamma} \tau \varepsilon$ (atau) yang merupakan partikel yang berfungsi menghubungkan ide-ide negatif, ${ }^{86}$ dan

80. Wanamaker, Thessalonians, 239.

81. Runge, Discourse Grammar, 18.

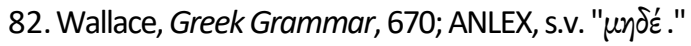

83. Runge, The Lexham Discourse Greek, 2Tes. 2:2.

84. Wanamaker, Thessalonians, 238; Cerone, Brannan, dan Lyle, 1-2 Thessalonians, 2Tes. 2:2.

85. Cerone, Brannan, dan Lyle, 1-2 Thessalonians, 2Tes. 2:2; Green, Thessalonians, 303.

86. BDAG, s.v. " $\mu \eta^{\prime} \tau \varepsilon$," ANLEX, s.v. " $\mu \eta^{\prime} \tau \varepsilon . "$ 
berfungsi menarik perhatian jemaat Tesalonika supaya mereka tidak diguncangkan dan ditakutkan oleh sumber pengajaran palsu. ${ }^{87}$

Sumber pengajaran palsu yang pertama adalah, "melalui roh" yang menyatakan bahwa sumber pengajaran palsu berasal dari ucapan nubuatan yang seolah-olah diilhami oleh Roh Kudus (bdk. 1Tes. 5:19) ${ }^{88}$ Sumber pengajaran palsu yang kedua adalah, "melalui perkataan" yang menyatakan bahwa sumber pengajaran palsu berasal dari pesan yang dikhotbahkan, diajarkan atau dipercakapkan (bdk. 1Tes. 4:15). ${ }^{89}$ Sumber pengajaran palsu yang ketiga adalah, "melalui surat seolah-olah dari kami" yang menyatakan bahwa sumber pengajaran palsu berasal dari surat yang seolah-olah ditulis oleh Paulus. ${ }^{90}$

Di ayat 2c, Paulus menjelaskan isi pengajaran palsu yang menjadi

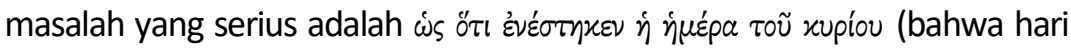
Tuhan telah tiba). ${ }^{91}$ Paulus menjelaskan isi pengajaran palsu dengan menggunakan partikel $\omega s$ yang memiliki arti "seolah-olah,"192 dan merujuk kepada fakta yang tidak benar. ${ }^{93}$ Fakta yang tidak benar tersebut adalah hari Tuhan telah tiba. ${ }^{94}$

Kesimpulan bagian ini (ayat 1-2) adalah: Paulus menguraikan permasalahan yang dialami jemaat Tesalonika mengenai kedatangan hari

87. Cerone, Brannan, dan Lyle, 1-2 Thessalonians, 2Tes. 2:2.

88. Weima, 1-2 Thessalonians, 504.

89. Green, Thessalonians, 303; Marshall, 1 and 2 Thessalonians, 186.

90. Green, Thessalonians, 304.

91. Cerone, Brannan, dan Lyle, 1-2 Thessalonians, 2Tes. 2:2.

92. BDAG, s.v "€s."

93. F. F. Bruce, 1 and 2 Thessalonians, WBC 45 (Dallas: Word, 2002), 240.

94. Bruce, 1 and 2 Thessalonians, 240. 
Tuhan. Paulus menasihati supaya mereka jangan cepat diguncangkan dan ditakutkan ketika mendengar berita yang mengabarkan bahwa hari Tuhan telah tiba. Paulus berkata bahwa pengajaran yang menyatakan hari Tuhan telah tiba adalah tidak benar.

Peristiwa-Peristiwa yang akan Mendahului Kedatangan Hari Tuhan (2 Tesalonika 2:3-4)

Setelah memaparkan mengenai permasalahan hari Tuhan di ayat 1-2, Paulus di ayat 3-4 menyatakan bahwa hari Tuhan belum tiba. Paulus berkata bahwa harus ada peristiwa-peristiwa tertentu yang akan mendahului sebelum hari Tuhan tiba. ${ }^{95}$

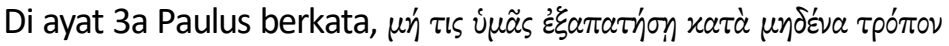
(jangan ada siapa pun memperdaya kalian menurut cara apa pun). Perkataan Paulus ini ditulis kembali secara negatif melalui keberadaan partikel $\mu \eta^{\prime}$ (jangan) yang menegaskan kembali posisi Paulus, yaitu jika ada orang yang mengajar jemaat Tesalonika bahwa hari Tuhan telah tiba, maka orang itu salah. ${ }^{96}$ Di ayat ini, Paulus menyisipkan informasi yang baru muncul yaitu kata ganti $\tau$ «s (siapa pun) di depan kata kerja "memperdaya" untuk dijadikan subjek. ${ }^{97}$ Penyisipan ini menjadikan "siapa pun" sebagai penekanan yang berfungsi menekankan nasihat Paulus supaya jemaat Tesalonika waspada terhadap siapa pun yang mungkin menjadi sumber

95. Weima, 1-2 Thessalonians, 489.

96. Cerone, Brannan, dan Lyle, 1-2 Thessalonians, 2Tes. 2:3. BDAG menjelaskan partikel $\mu$ ' sebagai penanda negasi (BDAG, s.v. " $\mu \eta^{\prime \prime}$ ).

97. Runge, The Lexham Discourse Greek, 2Tes. 2:3. 
penipuan dan akhirnya memperdaya mereka. ${ }^{98}$ Nasihat ini diuraikan Paulus lebih lanjut dengan frasa "menurut cara apa pun" dengan tujuan supaya jemaat Tesalonika berhati-hati terhadap tiga kemungkinan sumber pengajaran palsu yang bisa tampak seperti sumber otoritas yang lebih tinggi daripada Paulus. ${ }^{99}$

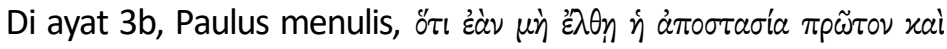

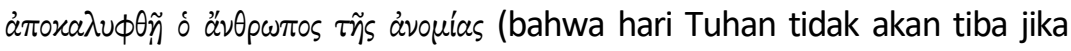
belum datang dahulu kemurtadan dan dinyatakan manusia durhaka, anak kebinasaan). Di ayat 3b ini terdapat markah wacana ö $\iota$ (bahwa) yang berfungsi sebagai penanda kausalitas. ${ }^{100}$ Markah wacana ö $\tau \iota$ berperan penting untuk menunjukkan alasan-alasan yang akan dipaparkan Paulus sampai ayat 12 bahwa pengajaran hari Tuhan telah tiba merupakan pengajaran yang salah. ${ }^{101} \mathrm{Di}$ ayat $3 \mathrm{~b}$ juga terdapat markah wacana xaí (dan) yang berfungsi memberi tanda adanya korelasi antara kemurtadan dengan kedatangan manusia durhaka sebagai dua tanda yang akan mendahului kedatangan hari Tuhan. ${ }^{102}$

Setelah markah wacana ö $\tau \iota$, Paulus menulis partikel çáv (jika) yang

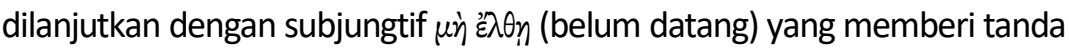
adanya protasis. ${ }^{103}$ Meski di dalam kalimat selanjutnya tidak terdapat

98. Cerone, Brannan, dan Lyle, 1-2 Thessalonians, 2Tes. 2:3.

99. Fee, Thessalonians, 279.

100. BDAG, s.v. "ö $\tau$; ;"Weima, 1-2 Thessalonians, 508.

101. Weima, 1-2 Thessalonians, 508.

102. Runge, Discourse Grammar, 23-24.

103. Wallace, Greek Grammar, 675. Wallace berkata bahwa partikel żáv merupakan konjungsi kondisional yang diterjemahkan "jika" (Wallace, Greek Grammar, 675). Protasis merupakan klausa yang menjelaskan syarat atau 
apodosis, ${ }^{104}$ pembaca dapat merekonstruksi apodosis dari ayat sebelumnya yang berbicara mengenai hari Tuhan telah tiba. ${ }^{105}$ Terjemahan penulis di artikel ini adalah, "bahwa hari Tuhan tidak akan tiba jika belum datang dahulu kemurtadan dan dinyatakan manusia durhaka."106

Paulus memberikan alasan pertama mengapa hari Tuhan belum tiba, yaitu belum datang dahulu kemurtadan. ${ }^{107}$ Alasan kedua mengapa hari Tuhan belum tiba berhubungan dengan identitas manusia durhaka yang belum dinyatakan Allah. ${ }^{108}$ Manusia durhaka merupakan orang yang memiliki karakter dan bertindak seolah-olah tidak ada hukum atau orang yang melanggar hukum. ${ }^{109}$ Pelanggaran hukum ini bukanlah pelanggaran terhadap hukum Musa tetapi melibatkan pelanggaran yang lebih luas, yaitu terhadap Tuhan dan kehendak-Nya. ${ }^{110}$ Paulus kemudian menguraikan lebih lanjut takdir manusia durhaka dengan istilah anak kebinasaan. ${ }^{111}$ Di dalam

pengandaian di dalam kalimat yang berisi persyaratan (Harimurti Kridalaksana, Kamus Linguistik, ed. ke-4 (Jakarta: Gramedia Pustaka Utama, 2008), 203).

104. Apodosis merupakan klausa yang menjelaskan akibat di dalam kalimat yang berisi persyaratan (Kridalaksana, Kamus Linguistik, 18).

105. Weima, 1-2 Thessalonians, 509; Grant R. Osborne, 1 \& 2 Thesalonians: Verse by Verse (Bellingham: Lexham, 2018), 172.

106. Weima, 1-2 Thessalonians, 508-9; Green, Thessalonians, 306-7.

107. Cerone, Brannan, dan Lyle, 1-2 Thessalonians, 2Tes. 2:3.

108. Cerone, Brannan, dan Lyle, 1-2 Thessalonians, 2Tes. 2:3; Paul Ellingworth dan Eugene A. Nida, Surat-Surat Paulus Kepada Jemaat di Tesalonika, terj. Kareasi H. Tambur dan Anwar Tjen, Pedoman Penafsiran Alkitab (Jakarta: LAl, 2001), 107.

109. Fee, Thessalonians, 280. Manusia durhaka biasanya diidentikkan dengan sosok yang disebut oleh rasul Yohanes sebagai antikristus (1Yoh. 2:18, 22; 4:3; 2Yoh. 7) dan binatang (Why. 13:1-8; 19:19-20) (Osborne, 1 \& 2 Thesalonians, 173; Marshall, 1 and 2 Thessalonians, 189).

110. Weima, 1-2 Thessalonians, 513; Marshall, 1 and 2 Thessalonians, 189.

111. Cerone, Brannan, dan Lyle, 1-2 Thessalonians, 2Tes. 2:3-4. 
ayat ini istilah anak kebinasaan memiliki arti, "manusia yang akan binasa atau manusia yang akan menerima kebinasaan kekal."112

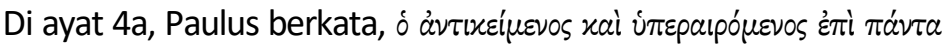

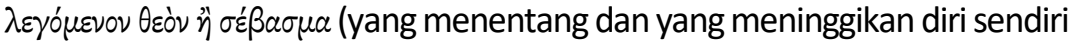
dengan sombong terhadap segala yang disebut Allah atau yang disembah). Di ayat 4a terdapat markah wacana xaí yang berfungsi memberi tanda adanya kelanjutan dan korelasi antara dua karakter manusia durhaka, yaitu ia menentang dan meninggikan diri sendiri. ${ }^{113} \mathrm{Di}$ ayat $4 \mathrm{~b}$, Paulus menulis

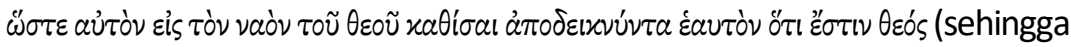
ia duduk di dalam Bait Allah, mengumumkan dirinya sebagai Allah). Keberadaan markah wacana $\omega ّ \sigma \tau \varepsilon$ (sehingga) memberi tanda inferensial dan hasil. ${ }^{114}$ Markah wacana "sehingga" di ayat 4b ini tidak mengungkapkan hasil sebenarnya tetapi hasil yang diinginkan, sehingga pembaca tidak perlu menyimpulkan bahwa manusia durhaka benar-benar secara nyata berhasil mengambil tempat duduk di Bait Allah, tetapi manusia durhaka menginginkan hasil untuk dapat duduk di Bait Allah. ${ }^{115}$

Di ayat $4 b$ terdapat kata ganti aủióv (ia) sebagai kerangka topikal, dan frasa preposisi "di dalam Bait Allah" sebagai penekanan karena merupakan informasi yang baru muncul dan berada di depan kata kerja "duduk." ${ }^{116}$ Kata ganti "ia" merupakan kerangka topikal yang berfungsi sebagai bingkai yang menarik perhatian ekstra jemaat Tesalonika kepada

112. Weima, 1-2 Thessalonians, 515; Green, Thessalonians, 309.

113. Runge, Discourse Grammar, 23-24; Green, Thessalonians, 309.

114. Levinsohn, "'"Therefore" or "Wherefore,"'" 334.

115. Marshall, 1 and 2 Thessalonians, 190; Weima, 1-2 Thessalonians, 517.

116. Runge, The Lexham Discourse Greek, 2Tes. 2:4. 
topik manusia durhaka dan menempatkan topik manusia durhaka di depan dan di tengah wacana, ${ }^{117}$ sedangkan frasa preposisi "di dalam Bait Allah" merupakan penekanan yang berfungsi memberi penekanan kepada jemaat Tesalonika bahwa apa pun yang akan dilakukan manusia durhaka akan berada di dalam Bait Allah. ${ }^{118}$

Paulus kemudian melanjutkan dengan menyatakan bahwa manusia durhaka "mengumumkan dirinya sebagai Allah." Perkataan Paulus ini menyatakan bahwa manusia durhaka tidak hanya duduk di Bait Allah, tetapi ia juga akan menyatakan secara eksplisit atau memproklamasikan kepada publik bahwa dirinya adalah Allah. ${ }^{119}$ Tindakan manusia durhaka ini menjelaskan karakter rohani dari manusia durhaka yang kurang ajar terhadap Allah. ${ }^{120}$

Perkataan Paulus di ayat 3 dan 4 tentang belum datangnya kemurtadan dan belum dinyatakan manusia durhaka tentunya memberi pemahaman kepada jemaat Tesalonika bahwa hari Tuhan pasti belum tiba. ${ }^{121}$ Penjelasan Paulus ini juga memberi konsekuensi bahwa pengajaran yang mengklaim hari Tuhan telah tiba adalah salah. ${ }^{122}$

117. Cerone, Brannan, dan Lyle, 1-2 Thessalonians, 2Tes. 2:4.

118. Cerone, Brannan, dan Lyle, 1-2 Thessalonians, 2Tes. 2:4.

119. Cerone, Brannan, dan Lyle, 1-2 Thessalonians, 2Tes. 2:4; Weima, 1-2 Thessalonians, 518.

120. Weima, 1-2 Thessalonians, 518.

121. Cerone, Brannan, dan Lyle, 1-2 Thessalonians, 2Tes. 2:4.

122. Cerone, Brannan, dan Lyle, 1-2 Thessalonians, 2Tes. 2:4. 
Penghakiman Allah Akan Terjadi Pada Kedatangan Hari Tuhan (2 Tesalonika 2:5-12)

Setelah di ayat 3-4, Paulus memaparkan belum datangnya kemurtadan dan belum dinyatakan manusia durhaka yang akan mendahului kedatangan hari Tuhan, Paulus di ayat 5-12 membahas tema penghakiman Allah yang akan terjadi pada kedatangan hari Tuhan. Tema penghakiman Allah ini tentunya memberi penghiburan kepada jemaat Tesalonika yang sedang mengalami penderitaan. ${ }^{123}$

Di ayat 5, Paulus bertanya kepada jemaat Tesalonika, Oủ

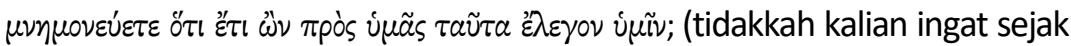
saya masih bersama-sama kalian karena hal-hal ini saya sudah katakan berulang kali kepada kalian?) Perlu diperhatikan bahwa di sini Paulus sebenarnya dapat berkata, "Ingat apa yang kami telah katakan tentang hari Tuhan."124 Tetapi, Paulus tidak berkata seperti itu karena ia ingin menarik perhatian jemaat Tesalonika. ${ }^{125}$ Untuk itu, Paulus secara khusus mengatur wacana sehingga jemaat Tesalonika dapat mengingat waktu dan isi pengajaran tentang hari Tuhan serta mengarahkan mereka kembali ke pemikiran yang benar. ${ }^{126}$

Pengaturan wacana dilakukan sebagai berikut, pertama, Paulus bertanya, "tidakkah kalian ingat.."127 Frasa "kalian ingat" yang berbentuk orang kedua jamak menggeser fokus dari topik sebelumnya yang berbicara

123. Fee, Thessalonians, 289-90.

124. Cerone, Brannan, dan Lyle, 1-2 Thessalonians, 2Tes. 2:5.

125. Cerone, Brannan, dan Lyle, 1-2 Thessalonians, 2Tes. 2:5.

126. Cerone, Brannan, dan Lyle, 1-2 Thessalonians, 2Tes. 2:5.

127. Cerone, Brannan, dan Lyle, 1-2 Thessalonians, 2Tes. 2:5. 
mengenai manusia durhaka kepada penerima surat, yaitu jemaat Tesalonika. ${ }^{128}$ Kedua, Paulus menulis kerangka temporal, yaitu "sejak saya masih bersama-sama kalian." ${ }^{129}$ Keberadaan kerangka temporal berfungsi sebagai bingkai dan menarik perhatian jemaat Tesalonika mengenai "waktu" yang memberi penjelasan bahwa Paulus pernah bersama-sama dengan mereka di masa lampau. ${ }^{130}$ Keberadaan kata "masih" juga menjelaskan fakta kehadiran Paulus di masa lampau ketika topik kedatangan hari Tuhan dibahas dan diajarkan kepada jemaat Tesalonika. ${ }^{131}$ Ketiga, terdapat kerangka topikal, yaitu $\tau \alpha \tilde{\tau} \tau \alpha$ (hal-hal ini) yang berada di depan kata kerja "katakan."132 Keberadaan kerangka topikal "hal-hal ini" berfungsi sebagai bingkai yang menyatakan isi topik pengajaran apa yang perlu diingat jemaat Tesalonika tentang hari Tuhan. ${ }^{133}$ Kerangka topikal ini diikuti oleh "saya sudah katakan" yang berfungsi untuk membedakan Paulus dengan rekan penulis lainnya dan mengidentifikasi bahwa Paulus merupakan guru utama dan sumber pengajaran yang perlu diingat oleh jemaat Tesalonika. ${ }^{134}$ Perlu diperhatikan bahwa tindakan Paulus yang mengajak jemaat Tesalonika untuk mengingat kembali apa yang telah mereka ketahui sudah dilakukan Paulus berulang kali (bdk. 1Tes. 2:9; 2Tes.

128. Cerone, Brannan, dan Lyle, 1-2 Thessalonians, 2Tes. 2:5.

129. Runge, The Lexham Discourse Greek, 2Tes. 2:5.

130. Runge, Discourse Grammar, 216.

131. Cerone, Brannan, dan Lyle, 1-2 Thessalonians, 2Tes. 2:5.

132. Runge, The Lexham Discourse Greek, 2Tes. 2:5.

133. Cerone, Brannan, dan Lyle, 1-2 Thessalonians, 2Tes. 2:5.

134. Cerone, Brannan, dan Lyle, 1-2 Thessalonians, 2Tes. 2:5; Green, Thessalonians, 314. 
3:10). ${ }^{135}$ Paulus juga sudah berulang kali menegaskan kebenaran yang telah diterima oleh jemaat Tesalonika (1Tes. 1:5; 2Tes. 3:7). ${ }^{136}$

Di ayat 6a, Paulus kembali menyapa jemaat Tesalonika dengan

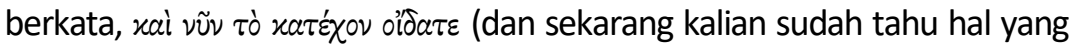
menahan). ${ }^{137} \mathrm{Di}$ ayat 6a ini terdapat kerangka temporal, yaitu "sekarang" yang berfungsi menarik perhatian jemaat Tesalonika kepada diskusi yang sedang terjadi di masa kini dan tidak lagi berfokus pada apa yang telah diajarkan Paulus di masa lalu. ${ }^{138}$ Setelah kerangka temporal "sekarang," Paulus menulis frasa "hal yang menahan" sebagai penekanan. ${ }^{139}$ Keberadaan frasa "hal yang menahan" sebagai penekanan disebabkan karena "hal yang menahan" merupakan frasa yang baru muncul di teks 2

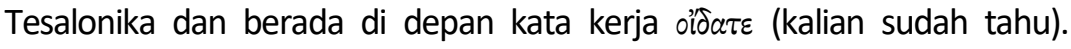
Penekanan di bagian ini berfungsi memberi penekanan kepada jemaat Tesalonika tentang adanya hal yang menahan manusia durhaka dinyatakan pada masa kini supaya jemaat Tesalonika dapat memahami bahwa klaim hari Tuhan telah tiba tidak mungkin benar. ${ }^{140}$ Dalam konteks ayat ini, frasa

135. Green, Thessalonians, 313.

136. Green, Thessalonians, 313.

137. Cerone, Brannan, dan Lyle, 1-2 Thessalonians, 2Tes: 2:6.

138. Runge, The Lexham Discourse Greek, 2Tes. 2:6; Runge, Discourse Grammar, 216; Cerone, Brannan, dan Lyle, 1-2 Thessalonians, 2Tes. 2:6.

139. Runge, The Lexham Discourse Greek, 2Tes. 2:6.

140. Cerone, Brannan, dan Lyle, 1-2 Thessalonians, 2Tes. 2:6; Weima, 1-2 Thessalonians, 526. 
"hal yang menahan" merujuk kepada hal yang menahan penyataan manusia durhaka. ${ }^{141}$

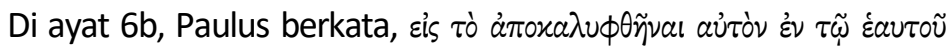

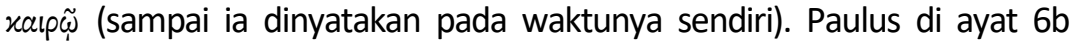
menjelaskan tujuan dari "hal yang menahan" adalah untuk memastikan bahwa penyataan manusia durhaka terjadi pada waktu yang telah ditentukan. ${ }^{142}$ Penyataan manusia durhaka selanjutnya dijelaskan secara temporer dengan frasa "pada waktunya sendiri."143 Kata ganti "sendiri" merupakan penekanan yang memberi penekanan supaya jemaat Tesalonika memahami bahwa manusia durhaka akan dinyatakan tepat sesuai dengan waktunya sendiri dan bukan sebelum waktunya. ${ }^{144}$

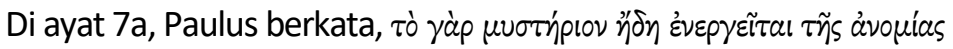
(karena misteri kedurhakaan telah sedang bekerja). Di ayat 7a ini terdapat

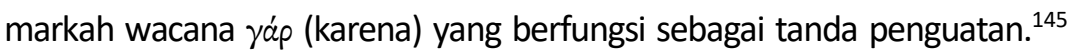
Dalam konteks ayat ini, markah wacana "karena" berfungsi memberi tanda adanya penjelasan lebih lanjut dari wacana sebelumnya yang membahas kehadiran "hal yang menahan" yang menahan manusia durhaka dinyatakan (ay. 3b-6). ${ }^{146}$ Paulus menjelaskan bahwa karena masih hadirnya "hal yang menahan" maka misteri kedurhakaan masih belum dapat

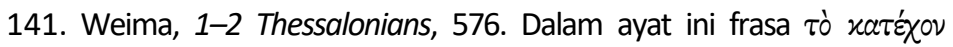
berbentuk netral. Kata $\varkappa a \tau \varepsilon ́ \chi \omega$ memiliki arti menahan, menghalangi, menahan (BDAG,

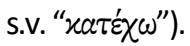

142. Cerone, Brannan, dan Lyle, 1-2 Thessalonians, 2Tes. 2:6.

143. Cerone, Brannan, dan Lyle, 1-2 Thessalonians, 2Tes. 2:6.

144. Runge, The Lexham Discourse Greek, 2Tes. 2:6; Cerone, Brannan, dan Lyle, 1-2 Thessalonians, 2Tes. 2:6; Green, Thessalonians, 317.

145. Levinsohn, Discourse Features, 91.

146. Cerone, Brannan, dan Lyle, 1-2 Thessalonians, 2Tes. 2:7. 
diidentifikasi dengan jelas sehingga manusia durhaka belum dinyatakan. ${ }^{147}$ Untuk itu jika ada yang mengklaim hari Tuhan telah tiba maka klaim tersebut adalah salah. ${ }^{148}$

Di ayat 7a terdapat kerangka topikal, yaitu "misteri kedurhakaan"

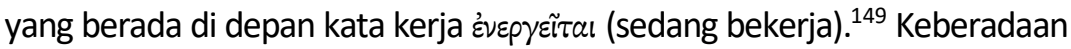
"misteri kedurhakaan" sebagai kerangka topikal berfungsi memberi penjelasan kembali natur yang tidak diketahui dari kehadiran manusia durhaka dan memungkinkan "misteri kedurhakaan" untuk dirujuk di dalam wacana selanjutnya sebagai satu entitas. ${ }^{150}$ Dari konteks ayat 9, dapat dipahami bahwa misteri kedurhakaan merupakan kekuatan jahat yang saat ini bekerja di bawah permukaan, tetapi ketika waktunya tiba pengungkapannya, ia akan mewujudkan diri dalam manifestasi manusia

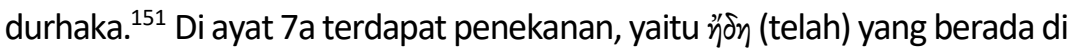

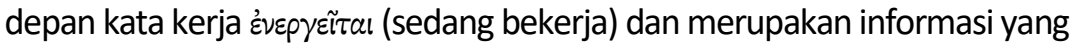
muncul di dalam teks. ${ }^{152}$ Keberadaan penekanan "telah" berfungsi memberi penekanan kepada jemaat Tesalonika bahwa misteri kedurhakaan sedang bekerja di masa kini sehingga mereka harus waspada akan adanya penipuan yang sedang bekerja di masa kini. ${ }^{153}$

147. Cerone, Brannan, dan Lyle, 1-2 Thessalonians, 2:7; Weima, 1-2 Thessalonians, 529.

148. Weima, 1-2 Thessalonians, 529.

149. Runge, The Lexham Discourse Greek, 2Tes. 2:7.

150. Runge, The Lexham Discourse Greek, 2Tes. 2:7; Cerone, Brannan, dan Lyle, 1-2 Thessalonians, 2Tes. 2:7.

151. Bruce, 1 and 2 Thessalonians, 170.

152. Runge, The Lexham Discourse Greek, 2Tes. 2:7.

153. Runge, The Lexham Discourse Greek, 2Tes. 2:7; Cerone, Brannan, dan Lyle, 1-2 Thessalonians, 2Tes. 2:7. 


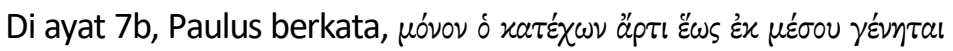
(hanya sekarang ada satu yang menahan, sampai yang menahan menjadi keluar dari tengah-tengah). ${ }^{154} \mathrm{Di}$ ayat ini terdapat kerangka topikal, yaitu

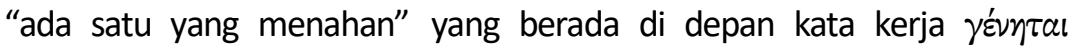
(menjadi). ${ }^{155}$ Keberadaan "ada satu yang menahan" sebagai kerangka topikal berfungsi mengaktifkan kembali keberadaan manusia durhaka di dalam wacana yang pernyataannya ditahan pada masa kini dan merujuk kembali kepada topik utama Paulus tentang waktu kedatangan hari Tuhan, yaitu kedatangan hari Tuhan belum tiba karena masih ditahannya penyataan manusia durhaka. ${ }^{156} \mathrm{Di}$ ayat $7 \mathrm{~b}$ terdapat penekanan, yaitu "keluar dari tengah-tengah" karena merupakan informasi yang baru

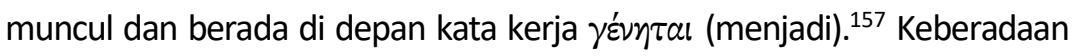
"keluar dari tengah-tengah" sebagai penekanan berfungsi memberi penekanan bahwa pada masa kini penahanan manusia durhaka masih akan terus terjadi sampai yang menahan keluar dari tengah-tengah atau tidak menahan manusia durhaka lagi. ${ }^{158}$ Perlu diperhatikan bahwa penulisan di ayat $7 \mathrm{~b}$ sebenarnya bisa dijelaskan lebih sederhana lagi, yaitu "manusia durhaka sedang ditahan," tetapi Paulus menuliskan kerangka topikal dan penekanan dengan maksud memberi penekanan tentang sifat dan otoritas pribadi yang menahan, yaitu bahwa hanya ada satu pribadi yang menahan

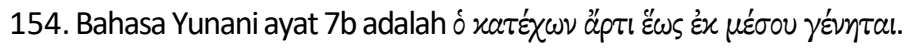

155. Runge, The Lexham Discourse Greek, 2Tes. 2:7.

156. Cerone, Brannan, dan Lyle, 1-2 Thessalonians, 2Tes. 2:7.

157. Runge, The Lexham Discourse Greek, 2Tes. 2:7.

158. Cerone, Brannan, dan Lyle, 1-2 Thessalonians, 2Tes. 2:7. 
dan penahanan akan berlanjut sampai pribadi yang menahan pergi tidak menahan manusia durhaka lagi. ${ }^{159}$

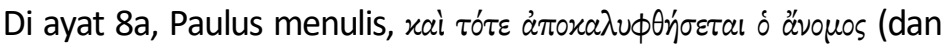
kemudian pendurhaka itu akan dinyatakan). Di ayat 8a terdapat markah wacana xaí (dan) yang berfungsi memberi tanda adanya kelanjutan penjelasan mengenai manusia durhaka yang ada di ayat sebelumnya. ${ }^{160} \mathrm{Di}$ ayat 8a juga terdapat markah wacana тó $\varepsilon$ (kemudian) berfungsi memberi tanda adanya keterkaitan dan perkembangan baru yang bersifat temporal di dalam suatu wacana, ${ }^{161}$ yaitu ketika manusia durhaka tidak ditahan lagi maka ia akan dinyatakan ke semua orang. ${ }^{162}$ Keberadaan markah wacana "kemudian" yang baru muncul di dalam teks 2 Tesalonika 2 dan berada di depan kata kerja dinyatakan menjadikan "kemudian" sebagai penekanan yang berfungsi memberi penekanan kepada jemaat Tesalonika bahwa waktu penyataan manusia durhaka itu penting. ${ }^{163}$ Jemaat Tesalonika perlu memahami bahwa di masa kini manusia durhaka masih ditahan dan belum dinyatakan untuk itu klaim yang menyatakan hari Tuhan telah tiba adalah salah. ${ }^{164}$

Paulus melanjutkan penjelasannya di ayat $8 \mathrm{~b}$ dengan berkata, ôv $\delta$

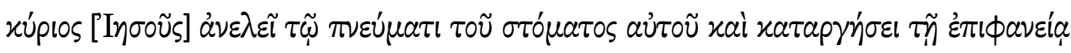

159. Cerone, Brannan, dan Lyle, 1-2 Thessalonians, 2Tes. 2:7.

160. Levinsohn, Discourse Features, 124; Cerone, Brannan, dan Lyle, 1-2 Thessalonians, 2Tes. 2:8.

161. Runge, Discourse Grammar, 38.

162. Cerone, Brannan, dan Lyle, 1-2 Thessalonians, 2Tes. 2:8.

163. Runge, The Lexham Discourse Greek, 2Tes. 2:8; Cerone, Brannan, dan Lyle, 1-2 Thessalonians, 2Tes. 2:8.

164. Runge, The Lexham Discourse Greek, 2Tes. 2:8; Cerone, Brannan, dan Lyle, 1-2 Thessalonians, 2Tes. 2:8. 


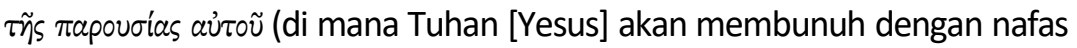
mulut-Nya dan akan memusnahkan pada saat penampakan kedatanganNya). Di ayat 8b ini terdapat kerangka topikal, yaitu "Tuhan [Yesus]" yang berfungsi memunculkan kembali Tuhan [Yesus] dalam pembahasan sebagai Pribadi yang berkuasa atas manusia durhaka. ${ }^{165}$ Kekuasaan Tuhan

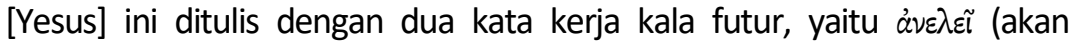

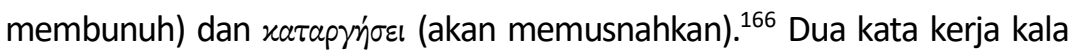
futur ini dihubungkan oleh markah wacana "dan" yang berfungsi memberi tanda aditif, ${ }^{167}$ yaitu menyatakan adanya korelasi tindakan Tuhan [Yesus] yang akan membunuh dan memusnahkan manusia durhaka. ${ }^{168}$ Perlu diperhatikan berkata bahwa keberadaan frasa "akan membunuh" dan "akan memusnahkan" di ayat ini menjelaskan konsep penghakiman Allah di masa depan di mana Tuhan [Yesus] merupakan Pribadi yang menjadi Hakim. ${ }^{169}$

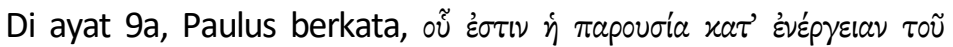
$\sum \alpha \tau \alpha v \tilde{a}$ (kedatangan manusia durhaka adalah sesuai dengan pekerjaan Setan). ${ }^{170}$ Perkataan Paulus ini menjelaskan bahwa kedatangan manusia durhaka adalah, "sesuai dengan pekerjaan Setan." Untuk itu ciri-ciri kedatangan manusia durhaka akan sesuai dengan pekerjaan Setan,

165. Runge, The Lexham Discourse Greek, 2Tes. 2:8; Cerone, Brannan, dan Lyle, 1-2 Thessalonians, 2Tes. 2:8.

166. Cerone, Brannan, dan Lyle, 1-2 Thessalonians, 2Tes. 2:8.

167. Levinsohn, Discourse Features, 124.

168. Runge, Discourse Grammar, 23-24.

169. Green, Thessalonians, 319-20.

170. Penulis di dalam artikel ini merujuk oũ kepada manusia durhaka dan bukan kepada Yesus Kristus karena rujukan ini sesuai dengan konteksnya (Weima, 12 Thessalonians, 537). 
sehingga sama seperti Setan bekerja di balik misteri kedurhakaan yang diam-diam bekerja di masa sekarang (ay. 7) begitu juga Setan bekerja di balik hambanya, yaitu manusia durhaka. ${ }^{171} \mathrm{Di}$ ayat 9b-10, Paulus menguraikan lebih lanjut mengenai informasi yang harus diperhatikan jemaat Tesalonika untuk dapat mengenali kedatangan manusia durhaka. ${ }^{172}$ Penjelasan ini ditulis dengan dua frasa preposisi yang dimulai dengan klausa "dengan segala." ${ }^{173}$ Paulus menjelaskan bahwa manusia durhaka akan datang, "dengan segala kekuatan dan mukjizat-mukjizat dan keajaibankeajaiban palsu" dan "dan dengan segala tipu daya kejahatan."174

Paulus melanjutkan wacana dengan berkata bahwa kedatangan manusia durhaka diarahkan kepada orang-orang yang sedang menuju kebinasaan dan bukan kepada jemaat Tesalonika. ${ }^{175}$ Alasan mengapa orang-orang tersebut sedang menuju kebinasaan adalah karena mereka tidak menerima kasih kebenaran sehingga mereka dapat diselamatkan. ${ }^{176}$

Perlu diperhatikan bahwa objek "kasih kebenaran" di ayat 10 merupakan informasi yang baru muncul dan ditampilkan di depan kata kerja "menerima" sehingga menjadi penekanan. ${ }^{177}$ Keberadaan "kasih

171. Weima, 1-2 Thessalonians, 538; Green, Thessalonians, 321.

172. Cerone, Brannan, dan Lyle, 1-2 Thessalonians, 2Tes. 2:9-10; Wanamaker, Thessalonians, 259.

173. Cerone, Brannan, dan Lyle, 1-2 Thessalonians, 2Tes. 2:9-10; Wanamaker, Thessalonians, 259.

174. Weima, 1-2 Thessalonians, 538.

175. Weima, 1-2 Thessalonians, 540.

176. Green, Thessalonians, 323.

177. Runge, The Lexham Discourse Greek, 2Tes. 2:10. Bahasa Yunani ayat

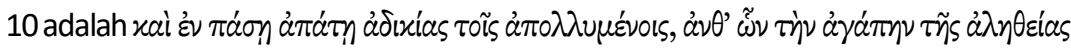

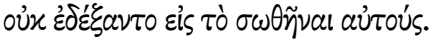


kebenaran" sebagai penekanan berfungsi memberi penekanan dan menarik lebih banyak perhatian kepada jemaat Tesalonika bahwa kebinasaan akan terjadi kepada orang-orang yang tidak menerima kasih kebenaran. ${ }^{178}$ Kebenaran yang dimaksud Paulus adalah Injil Kristus yang telah diberitakan kepada jemaat Tesalonika (ay. 12-14; bdk. Gal. 2:5, 14; Ef. $1: 13) .{ }^{179}$

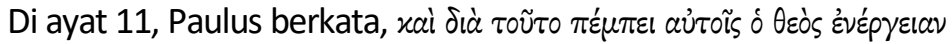

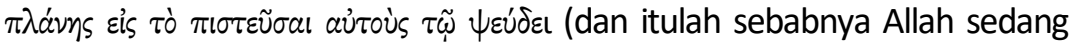
mengirim kepada mereka pekerjaan yang menyesatkan supaya mereka percaya kepada kepalsuan). Di awal ayat ini terdapat markah wacana xaí yang memberi tanda adanya hubungan antara perkataan Paulus di ayat 11 dengan ayat $10{ }^{180}$ Adanya hubungan ini ditandai kembali oleh keberadaan markah wacana "dan itulah" yang berfungsi untuk memberi tanda inferensial dan spesifik tematik, ${ }^{181}$ maksudnya markah wacana "dan itulah" berfungsi menandai adanya sebab akibat antara ayat 10 dengan ayat $11 .{ }^{182}$ Di ayat 11, markah wacana "dan itulah" juga menjadi kerangka alasan atau hasil karena berada di depan kata kerja "sedang mengirim." ${ }^{183}$ Keberadaan markah wacana "dan itulah" sebagai kerangka alasan atau hasil berfungsi menarik perhatian jemaat Tesalonika bahwa hasil dari orang-orang yang

178. Cerone, Brannan, dan Lyle, 1-2 Thessalonians, 2Tes. 2:10.

179. Green, Thessalonians, 323.

180. Levinsohn, Discourse Features, 124.

181. Levinsohn, "'"Therefore" or "Wherefore,"'" 336.

182. Runge, Discourse Grammar, 49-50.

183. Runge, The Lexham Discourse Greek, 2Tes. 2:11. 
tidak mau menerima kasih kebenaran adalah Allah melaksanakan penghakiman-Nya di masa kini. ${ }^{184}$

Penghakiman Allah di masa kini dijelaskan Paulus dengan berkata, "Allah sedang mengirim kepada mereka pekerjaan yang menyesatkan."185 Di dalam perkataan ini terdapat kata benda "pekerjaan" yang mengacu kepada pekerjaan yang dilakukan bukan oleh manusia, tetapi oleh Pribadi transenden, yaitu Allah (Ef. 1:19; Flp. 3:21) atau Setan (2Tes. 2:9). ${ }^{186}$ Keberadaan Pribadi transenden sebagai sumber yang melakukan "pekerjaan" menyatakan bahwa "pekerjaan yang menyesatkan" memiliki kekuatan yang sangat kuat. ${ }^{187}$

Tujuan Allah mengirim pekerjaan yang menyesatkan kepada orang-orang yang sedang menuju kebinasaan (ay. 10a) adalah supaya mereka percaya kepada kepalsuan. ${ }^{188}$ Keberadaan kata "kepalsuan" yang berbentuk tunggal dan tidak merujuk kepada kepalsuan yang umum, tetapi kepada kepalsuan yang spesifik. ${ }^{189}$ Untuk memahami apa yang dirujuk dengan "kepalsuan" dapat diperhatikan di ayat 9 di mana kata kepalsuan pertama kali muncul. ${ }^{190}$ Di ayat 9, kata "kepalsuan" menjelaskan karakter palsu dari mukjizat dan keajaiban yang dilakukan oleh manusia durhaka

184. Runge, Discourse Grammar, 49-50; Green, Thessalonians, 323-24.

185. Osborne, $1 \& 2$ Thesalonians, 183.

186. Weima, 1-2 Thessalonians, 534; Osborne, 1 \& 2 Thesalonians, 183.

187. Weima, 1-2 Thessalonians, 534; Osborne, 1 \& 2 Thesalonians, 183.

188. Wanamaker, Thessalonians, 262.

189. Weima, 1-2 Thessalonians, 534.

190. Wanamaker, Thessalonians, 262. 
pada kedatangannya, ${ }^{191}$ dan di ayat 11 Allah memastikan bahwa kepalsuan inilah yang dipilih secara efektif oleh mereka yang akan binasa. ${ }^{192}$ Kesimpulannya, bagi Paulus kegagalan seseorang untuk menerima kasih kebenaran berdampak kepada tindakan Allah yang mengirim pekerjaan yang menyesatkan sehingga orang-orang akan percaya kepada kepalsuan. ${ }^{193}$

Gagasan bahwa Allah mengirim kepada orang yang akan binasa pekerjaan yang menyesatkan sehingga mereka dihukum mungkin akan menimbulkan pertanyaan, yaitu mengapa Allah terlibat pada pekerjaan yang jahat sehingga orang dapat percaya kepada kepalsuan dan akhirnya mereka dihukum ${ }^{194}$ Terdapat pemahaman untuk menjawab pertanyaan ini, yaitu kerangka alasan atau hasil "dan itulah" yang ada di awal ayat 11 tidak boleh diabaikan karena memberi penjelasan bahwa Allah bertindak bukan sebagai Pribadi yang menyebabkan, tetapi sebagai Pribadi yang memberi konsekuensi atas orang-orang yang sebelumnya menolak kebenaran Injil. ${ }^{195}$ Gordon D. Fee berkata bahwa tindakan Allah yang mengirim pekerjaan yang menyesatkan merupakan bentuk penghakiman Allah kepada orang-orang yang telah menolak belas kasihan Allah. ${ }^{196}$

191. Wanamaker, Thessalonians, 262. Lihat juga pendapat lain, yaitu dari Weima yang berkata bahwa kepalsuan merujuk kepada penolakan Injil (Weima, 1-2 Thessalonians, 544).

192. Wanamaker, Thessalonians, 262.

193. Fee, Thessalonians, 295.

194. Wanamaker, Thessalonians, 262; Fee, Thessalonians, 295.

195. Weima, 1-2 Thessalonians, 545.

196. Fee, Thessalonians, 295. 
Di ayat 12 , Paulus menyatakan bahwa hasil akhir dari penolakan orang terhadap kasih kebenaran dan tindakan Allah yang mengirim pekerjaan yang menyesatkan adalah mereka dihukum. ${ }^{197}$ Paulus berkata,

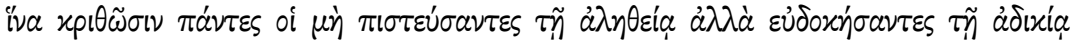
(supaya dihukum semua orang yang tidak percaya kepada kebenaran tetapi menyukai perbuatan yang jahat). ${ }^{198}$ Di dalam kalimat ini terdapat partikel iva (supaya) yang dilanjutkan dengan subjungtif $x p ı \theta \tilde{\omega} \sigma \nu$ (supaya dihukum) yang berfungsi menjelaskan bahwa hukuman merupakan bagian dari tujuan Allah kepada semua orang yang tidak percaya kepada kebenaran dan yang menyukai perbuatan yang jahat. ${ }^{199}$

Paulus kemudian mengidentifikasi orang yang dihukum sebagai, "orang yang tidak percaya kepada kebenaran" dan "yang menyukai perbuatan yang jahat." ${ }^{200}$ Kata kebenaran dan kejahatan muncul berpasangan di ayat ini untuk menyatakan bahwa pemahaman intelektual akan kebenaran memiliki keterkaitan dengan tingkah laku yang benar. ${ }^{201}$ Perlu diperhatikan bahwa dua identifikasi orang yang tidak percaya kepada kebenaran dan yang menyukai perbuatan yang jahat dihubungkan oleh markah wacana $\alpha \lambda \lambda \alpha \dot{~(t e t a p i) ~ y a n g ~ b e r f u n g s i ~ m e m b e r i ~ t a n d a ~ k o r e k t i f . ~}{ }^{202}$ Dalam ayat ini markah wacana "tetapi" berfungsi menjelaskan kepada

197. Weima, 1-2 Thessalonians, 544; Fee, Thessalonians, 295.

198. Wanamaker, Thessalonians, 262.

199. BDAG, s.v. "iva;" Mounce, Basics of Biblical Greek, 359; Cerone, Brannan, dan Lyle, 1-2 Thessalonians, 2Tes. 2:12; Wanamaker, Thessalonians, 262.

200. John Bryon, 1 and 2 Thessalonians, Story of God Bible commentary (Grand Rapids: Zondervan, 2014), 263.

201. Weima, 1-2 Thessalonians, 545.

202. Fresch, "Discourse Markers," 151, 169. 
jemaaat Tesalonika bahwa mereka yang dihukum diidentifikasi tidak hanya orang yang tidak percaya kepada kebenaran, tetapi juga orang yang menyukai perbuatan yang jahat. ${ }^{203}$ Jadi alasan Allah melakukan penghukuman bukan hanya karena orang tidak percaya kepada kebenaran, tetapi karena mereka menyukai perbuatan yang jahat. ${ }^{204}$

Kesimpulan bagian ini (ayat 5-12) adalah: Paulus menguraikan penghakiman Allah yang akan terjadi di masa kini dan di masa depan ketika Yesus datang. Paulus menjelaskan bahwa penghakiman Allah akan terjadi kepada orang-orang yang tidak percaya, yaitu manusia durhaka (ay. 8), orang-orang yang menolak berita Injil (ay. 10) dan yang menyukai perbuatan jahat (ay. 12).

\section{Bentuk Penghakiman Allah di 2 Tesalonika 2:1-12}

Di atas telah dipaparkan eksegesis penghakiman Allah di 2 Tesalonika 2:1-12 menurut pendekatan AW. Berdasarkan eksegesis di atas akan dijelaskan bentuk penghakiman Allah sebagai berikut, pertama, agen yang menjadi Hakim di dalam penghakiman Allah adalah Yesus Kristus dan Allah. Keberadaan Yesus Kristus sebagai Hakim dijelaskan melalui tindakan Yesus di masa depan yang berkuasa membunuh dan memusnahkan manusia durhaka pada saat kedatangan-Nya (ay. 8). ${ }^{205}$ Keberadaan Allah sebagai Hakim dijelaskan melalui tindakan Allah yang menghukum semua orang yang tidak percaya kepada kebenaran dan yang menyukai perbuatan jahat (ay. 12).

203. Cerone, Brannan, dan Lyle, 1-2 Thessalonians, 2Tes. 2:12.

204. Cerone, Brannan, dan Lyle, 1-2 Thessalonians, 2Tes. 2:12.

205. Green, Thessalonians, 319-20. 
Kedua, tindakan penghakiman Allah dapat diperhatikan melalui tiga tindakan berikut ini: (1) tindakan Yesus yang membunuh dan memusnahkan manusia durhaka (ay. 8); (2) tindakan Allah yang sedang mengirim pekerjaan yang menyesatkan kepada orang-orang yang akan binasa (ay. 11), ${ }^{206}$ (3) tindakan Allah yang menghukum semua orang yang tidak percaya kepada kebenaran dan yang menyukai perbuatan jahat (ay. 12). Tiga tindakan di atas menjelaskan konsep penghakiman Allah yang terdapat di 2 Tesalonika 2:1-12.

Ketiga, dasar penghakiman Allah adalah menurut perbuatan yang dilakukan seseorang. Paulus menyatakan bahwa manusia durhaka akan menerima penghakiman Allah karena ia menentang, meninggikan diri dengan sombong, ingin disembah sebagai Allah dan mengumumkan dirinya sebagai Allah (ay. 4). Perbuatan lain yang menjadi dasar penghakiman adalah tidak menerima kasih dan kebenaran (ay. 10), tidak percaya akan kebenaran dan menyukai perbuatan jahat (ay. 12). ${ }^{207}$

Keempat, objek penghakiman Allah adalah semua umat manusia, baik orang percaya atau tidak percaya. Paulus memberi nasihat supaya jemaat Tesalonika jangan cepat diguncangkan dan ditakutkan oleh sumbersumber yang mengatakan bahwa hari Tuhan telah tiba (ay.2). Paulus juga menasihatkan jangan ada siapa pun yang memperdaya jemaat Tesalonika (ay. 3). Nasihat-nasihat ini memberi pemahaman bahwa Allah akan menghakimi jemaat Tesalonika jika mereka lalai dalam memperhatikan nasihat-nasihat tersebut. Paulus juga menyatakan bahwa orang yang tidak 
percaya, yaitu manusia durhaka (ay. 8), orang yang menolak berita Injil (ay. 10) dan yang menyukai perbuatan jahat akan menerima penghakiman Allah (ay. 12).

Kelima, waktu penghakiman Allah akan terjadi di masa kini dan masa depan. Penghakiman Allah terjadi di masa kini, yaitu ketika Allah sedang mengirim orang-orang yang akan binasa suatu pekerjaan yang menyesatkan sehingga mereka percaya kepada kepalsuan (ay. 11). ${ }^{208}$ Penghakiman Allah akan terjadi di masa depan ketika manusia durhaka akan dibunuh dan dimusnahkan pada saat kedatangan Tuhan Yesus (ay.8). ${ }^{209}$ Penghakiman Allah juga akan terjadi di masa depan ketika Allah menghukum semua orang yang tidak percaya kepada kebenaran dan yang menyukai perbuatan jahat (ay. 12). ${ }^{210}$

\section{Fungsi Motif Penghakiman Allah di 2 Tesalonika 2:1-12}

Penghakiman Allah yang terdapat di 2 Tesalonika 2:1-12 berfungsi menghibur dan menguatkan jemaat Tesalonika supaya mereka tidak guncang dan takut dari klaim palsu yang menyatakan bahwa hari Tuhan telah tiba (ay. 2). ${ }^{211}$ Penghiburan dan penguatan yang diberikan Paulus dijelaskan lebih lanjut di ayat 1-12.

Perikop 2 Tesalonika 2:1-2 memperkenalkan masalah yang dialami jemaat Tesalonika, yaitu adanya klaim palsu bahwa hari Tuhan telah tiba. ${ }^{212}$

208. Osborne, 1 \& 2 Thesalonians, 183.

209. Green, Thessalonians, 320.

210. Weima, 1-2 Thessalonians, 544; Wanamaker, Thessalonians, 262.

211. Weima, 1-2 Thessalonians, 489.

212. Weima, 1-2 Thessalonians, 489. 
Di perikop ini Paulus sebagai seorang gembala tidak menutup mata ketika ada masalah di jemaatnya. Paulus di ayat $1 \mathrm{~b}$ segera menetapkan kerangka acuan melalui frasa preposisi, "mengenai kedatangan Tuhan kita Yesus Kristus dan terhimpunnya kita dengan-Nya." ${ }^{213}$ Paulus di perikop ini juga memberikan penghiburan dengan menulis penekanan, yaitu kata keterangan "cepat" supaya jemaat tidak cepat diguncangkan dan ditakutkan ketika mendengar klaim pengajaran palsu yang berkata hari Tuhan telah tiba (ay. 2). ${ }^{214}$ Keberadaan istilah "dan juga" menambahkan negasi nasihat Paulus supaya jemaat Tesalonika tidak diguncangkan dan ditakutkan dari sumber-sumber yang berkata bahwa hari Tuhan telah tiba. ${ }^{215}$

Perikop 2 Tesalonika 2:3-12 menguraikan koreksi Paulus atas klaim palsu bahwa hari Tuhan telah tiba. ${ }^{216}$ Di perikop ini Paulus berkata kepada jemaat Tesalonika jangan ada siapa pun memperdaya mereka (ay. 3a). Kata ganti "siapa pun" berfungsi sebagai penekanan yang memberi penekanan kepada nasihat Paulus supaya jemaat Tesalonika waspada terhadap siapa pun yang mungkin menjadi sumber penipuan. ${ }^{217}$ Bagi Paulus, hari Tuhan belum tiba karena peristiwa di masa depan ini tidak akan terjadi sampai terjadi dahulu kemurtadan dan dinyatakan manusia durhaka. ${ }^{218}$

213. Runge, The Lexham Discourse Greek, 2Tes. 2:1.

214. Wanamaker, Thessalonians, 238; Cerone, Brannan, dan Lyle, 1-2 Thessalonians, 2Tes. 2:2.

215. Runge, Discourse Grammar, 18.

216. Weima, 1-2 Thessalonians, 489.

217. Runge, The Lexham Discourse Greek, 2Tes. 2:3; Cerone, Brannan, dan Lyle, 1-2 Thessalonians, 2Tes. 2:3.

218. Weima, 1-2 Thessalonians, 489. 
Paulus menjelaskan bahwa karakter utama manusia durhaka yang perlu mendapat penekanan adalah, "sehingga ia duduk di dalam Bait Allah" (ay. 4b). ${ }^{219}$ Di ayat 4b, frasa preposisi "di dalam Bait Allah" merupakan penekanan yang berfungsi memberi penekanan kepada jemaat Tesalonika bahwa apa pun yang akan dilakukan manusia durhaka akan berada di dalam Bait Allah.220

Paulus di dalam ayat 10 menyatakan bahwa penghakiman Allah akan terjadi juga kepada para pengikut manusia durhaka, yaitu orang-orang yang tidak menerima kasih kebenaran. ${ }^{221}$ Objek kasih kebenaran di ayat 10 merupakan penekanan, ${ }^{222}$ yang berfungsi memberi penekanan kepada jemaat Tesalonika bahwa kebinasaan akan terjadi kepada orang-orang yang tidak menerima kasih kebenaran. ${ }^{223}$ Kebenaran yang dimaksud adalah berita Injil Kristus yang telah diberitakan kepada jemaat Tesalonika (ay. 1214; bdk. Gal. 2:5, 14; Ef. 1:13).224

Paulus berkata di ayat 11, "dan itulah sebabnya Allah sedang mengirim kepada mereka pekerjaan yang menyesatkan supaya mereka percaya kepada kepalsuan." Keberadaan "dan itulah" di ayat ini merupakan kerangka alasan atau hasil yang berfungsi menarik perhatian jemaat Tesalonika bahwa hasil dari penolakan orang-orang kepada kebenaran adalah Allah melaksanakan penghakiman-Nya. ${ }^{225}$ Bentuk tindakan

219. Cerone, Brannan, dan Lyle, 1-2 Thessalonians, 2Tes. 2:4.

220. Cerone, Brannan, dan Lyle, 1-2 Thessalonians, 2Tes. 2:4.

221. Weima, 1-2 Thessalonians, 489.

222. Runge, The Lexham Discourse Greek, 2Tes. 2:10.

223. Cerone, Brannan, dan Lyle, 1-2 Thessalonians, 2Tes. 2:10.

224. Green, Thessalonians, 323.

225. Runge, Discourse Grammar, 49-50; Green, Thessalonians, 323. 
penghakiman Allah dijelaskan Paulus dengan berkata, "Allah sedang mengirim kepada mereka pekerjaan yang menyesatkan."226 Tujuan Allah mengirim pekerjaan yang menyesatkan kepada orang-orang yang binasa adalah, "supaya mereka percaya kepada kepalsuan."227 Paulus di ayat 12 menjelaskan bahwa hasil akhir dari penolakan orang terhadap kasih kebenaran dan tindakan Allah yang mengirim pekerjaan yang menyesatkan adalah mereka dihukum. ${ }^{228}$

Penghakiman Allah yang membunuh manusia durhaka dan menghukum para pengikut manusia durhaka tentunya memberi penghiburan kepada jemaat Tesalonika, karena penghakiman Allah menunjukkan kemenangan Tuhan Yesus terhadap kekuatan jahat, 229 membuktikan kebenaran iman jemaat Tesalonika kepada Yesus Kristus dan menunjukkan bahwa penghakiman Allah itu adil.. ${ }^{230}$ Penghakiman Allah kepada manusia durhaka dan para pengikutnya juga memberikan pengharapan bahwa musuh jemaat Tesalonika adalah musuh Allah dan mereka akan dihukum. ${ }^{231}$

\section{Kesimpulan}

Di artikel ini, penulis telah menguraikan bahwa teks 2 Tesalonika 2:1-12 merupakan teks yang berbicara mengenai penghakiman Allah yang

226. Green, Thessalonians, 323.

227. Wanamaker, Thessalonians, 262.

228. Weima, 1-2 Thessalonians, 544.

229. Michael Holmes, 1 and 2 Thessalonians, NIVAC (Grand Rapids: Zondervan, 1998), 250.

230. Weima, 1-2 Thessalonians, 489.

231. Bryon, 1 and 2 Thessalonians, 263. 
adil. Keberadaan penghakiman Allah yang adil dilatarbelakangi oleh adanya klaim di dalam jemaat Tesalonika bahwa hari Tuhan telah tiba. Fungsi motif penghakiman Allah adalah memberikan penghiburan dan pengharapan kepada jemaat Tesalonika bahwa penghakiman Allah itu adil dan Allah akan menghukum setiap orang yang tidak percaya kepada Yesus Kristus dan yang tidak mau menerima berita Injil. ${ }^{232}$

\section{Daftar Pustaka}

\section{Buku}

Aernie, Matthew D., dan Donald E. Hartley. The Righteous and Merciful Judge. Bellingham: Lexham, 2018.

Bruce, F. F. 1 and 2 Thessalonians. WBC 45. Dallas: Word, 2002.

Bryon, John. 1 and 2 Thessalonians. Story of God Bible commentary. Grand Rapids: Zondervan, 2014.

Campbell, Constantine R. Advances in the Study of Greek. Grand Rapids: Zondervan, 2015.

Cerone, Jacob N., Rick Brannan, dan Kristopher A. Lyle. 1-2 Thessalonians. Diedit oleh Steven E. Runge. Lexham Discourse Commentary. Bellingham: Lexham Press, 2018.

Dik, Simon C. The Theory of Functional Grammar: Part l: The Structure of the Clause. Diedit oleh Kees Hengeveld. Ed. ke-2. Berlin: Moulton de Gruyter, 1997.

Ellingworth, Paul, dan Eugene A. Nida. Surat-Surat Paulus Kepada Jemaat di Tesalonika. Diterjemahkan oleh Kareasi H. Tambur dan Anwar Tjen. Pedoman Penafsiran Alkitab. Jakarta: LAl, 2001.

Fee, Gordon D. The First and Second Letters to the Thessalonians. NICNT. Grand Rapids: Eerdmans, 2009.

Fresch, Christopher James. "Discourse Markers in the Septuagint and Early Koine Greek with Special Reference to The Twelve." Disertasi Ph.D, University of Cambridge, 2015.

Green, Gene L. The Letters to the Thessalonians. PNTC. Grand Rapids: Eerdmans, 2002. 
Hamilton Jr., James M. God's Glory in Salvation Through Judgment: A Biblical Theology. Wheaton: Crossway, 2010.

Holmes, Michael. 1 and 2 Thessalonians. NIVAC. Grand Rapids: Zondervan, 1998.

Joihin, Jonly. "A Functional Description of the Discourse Marker $\Delta \mathrm{E}$ in 1 Corinthians." Disertasi Ph.D, The Southern Baptist Theological Seminary, 2019.

Kridalaksana, Harimurti. Kamus Linguistik. Ed. ke-4. Jakarta: Gramedia Pustaka Utama, 2008.

Levinsohn, Stephen H. "A Holistic Approach to the Argument Structure of Romans 6," makalah dipresentasikan pada pertemuan Society of Biblical Literature di London, Inggris, Juli 2001. . Discourse Features of New Testament Greek. Edisi kedua. Dallas: SIL International, 2000.

. "Eight Constraints on the Interpretation of Luke 17:11-19," makalah dipresentasikan pada pertemuan Society of Biblical Literature di Vienna, Austria, Juli 2014.

. "Some Constraints on Discourse Development in the Pastoral Epistles." Dalam Discourse Analysis and the New Testament: Approaches and Results, diedit oleh Stanley E. Porter dan Jeffrey T. Reed. JSNTS. Sheffield: Sheffield Academic, 1999.

. "'Therefore" or "Wherefore": What's the Difference?" Dalam Explorations in Ancient Syriac, Hebrew, and Greek Sources, diedit oleh Richard A. Taylor dan Craig E. Morrison. Piscataway: Gorgias Press, 2014.

Malherbe, Abraham J. The Letters to the Thessalonians. AYB. New Haven: Yale, 2008.

Marshall, I. Howard. 1 and 2 Thessalonians. NCB. Grand Rapids: Eerdmans, 1983.

Morris, Leon. Teologi Perjanjian Baru. Diterjemahkan oleh H. Pidyarto O Carm. Malang: Gandum Mas, 2006.

Mounce, William D. Basics of Biblical Greek Grammar. Ed. ke-4. Grand Rapids: Zondervan, 2019.

Osborne, Grant R. 1 \& 2 Thesalonians: Verse by Verse. Bellingham: Lexham, 2018.

Porter, Stanley E. "Discourse Analysis and New Testament Studies: An Introductory Survey." Dalam Discourse Analysis and Other Topics in 
Biblical Greek, diedit oleh Stanley E. Porter dan D. A. Carson. JSNTS 113. Sheffield: Sheffield Academic, 1995.

Robertson, A. T. A Grammar of the Greek New Testament in the Light of Historical Research. Bellingham: Logos Research Systems, 2006.

Runge, Steven E. Discourse Grammar of the Greek New Testament. Peabody: Hendrickson, 2010.

. "Interpreting Constituent Order in Koine Greek." Dalam Linguistics and New Testament Greek, diedit oleh David Alan Black dan Benjamin L. Merkle. Grand Rapids: Baker Academic, 2020.

. "Introduction: Why We're Honoring Stephen H. Levinsohn." Dalam Discourse Studies and Biblical Interpretation: A Festschrift in Honor of Stephen H. Levinsohn, diedit oleh Steven E. Runge. Bellingham: Logos Bible Software, 2011.

. "Questions From Your Book: Discourse Grammar." Diwawancara oleh Alexander Darmawan Limasaputra. E-mail, 10 Juni 2020.

. The Lexham Discourse Greek New Testament. Bellingham: Logos Research Systems, 2008.

. The Lexham Discourse Greek New Testament: Glossary. Bellingham: Lexham Press, 2008.

Wallace, Daniel B. Greek Grammar Beyond the Basics. Grand Rapids: Zondervan, 1996.

Wanamaker, Charles A. The Epistles to the Thessalonians. NIGTC. Grand Rapids: Eerdmans, 1990.

Weima, Jeffrey A. D. 1-2 Thessalonians. BECNT. Grand Rapids: Baker Academic, 2014.

\section{Jurnal}

Limasaputra, Alexander Darmawan. "Bukti Penghakiman Allah Yang Adil di dalam 2 Tesalonika 1:3-10 Menurut Pendekatan Analisis Wacana." Veritas: Jurnal Teologi dan Pelayanan 19, no. 1 (Juni 2020): 69-84. Diakses 5 Agustus 2021. DOI: https://doi.org/10.36421/veritas. v19i1.349 